\title{
AMENDMENTS TO THE CONSTITUTION OF IOWA
}

\author{
By David C. Motт
}

\section{Amendments Submitted and Adopted I}

Note--All historical statements concerning the adoption of all the amendments are quoted from "The Constitution of the State of Iowa and Amendments from 1857 to 1919, with Historical Introduction," prepared for publication by W. C. Ramsay, Secretary of State.

Facsimiles of the first, second, third, fourth, and fifth amendments as engrossed and enrolled with the manuscript acts and joint resolutions of the Twelfth General Assembly, 1868:

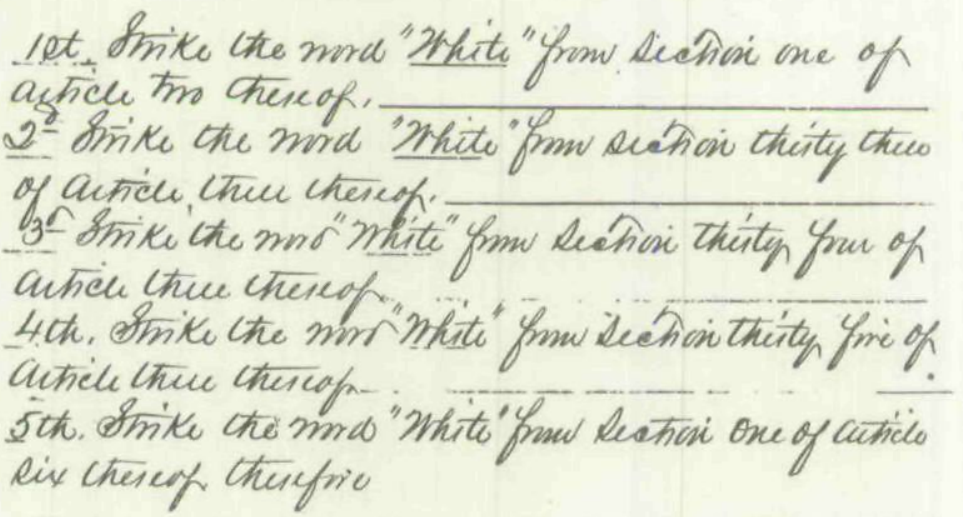

These amendments were proposed by the Eleventh General Assembly, 1866, agreed to by the Twelfth General Assembly, 1868, ratified at the general election of November 3, 1868, and proclaimed $^{1}$ adopted on December 8, 1868.

1The Twelfth General Assembly, in agreeing to these amendments, encied that if they should be adopted by the eleciorate, the governor should issne a proclamation announcing the fact. Governor Merrill proclaimed them to be a part of the Constitution. (See Iowa Slate Register, December 12, 1868, in the Newspaper Division of the Historic I Dep.rtment.) The Sixteenth General Assembly enacted that the returns of the votes on constitutional amendments should "be made in the same manner and by the same officers, and like returns be made thereof, as of the ballots cast for the secretary of state." and that they should declare the result and enter the same of record with the secretary of state. Thereafter the General Assembly, when agreeing to an amendment, did not direct the governor, in case of the adoption of an amendment by the people, to make proclamation of that fact, but left the canvassing board to certify the fact to the secretary of state; except, however, the Nineteenth General Assembly, when it agreed to the Prohibition Amendment directed that after it should be submitted to a vote of the people, the governor should "issue his proclamation declaring the result." Governor Sherman did this. (See Walerloo Reporter of Angust 2, 1882, in the Newspaper Division of the Historieal Department.) 
Facsimile of the sixt' 1 amendment as enzrossed and enrolled with the manuscript acts an 1 joint rcsolutions of the Eighteent' General Assembly, 1880:

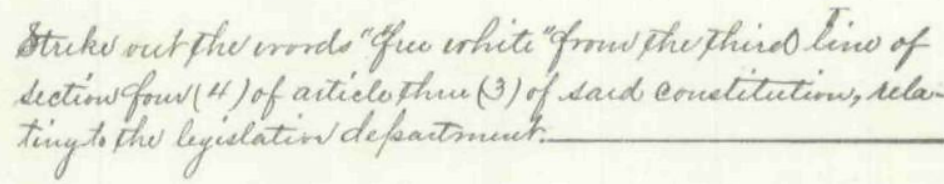

This amendment was proposed by the Seventeenth General Assembly, 1878, agreed to by the Eighteenth Gencral Assembly, 1880, ratified at the general election of November 2, 1880, and certified adopted on December 3, 1880.

Facsimiles of the seventh, eighth, ninth, and tenth amendments as engrossed and enrolled with the manuscript acts and joint resolutions of the Twentieth General Assembly, 1884:

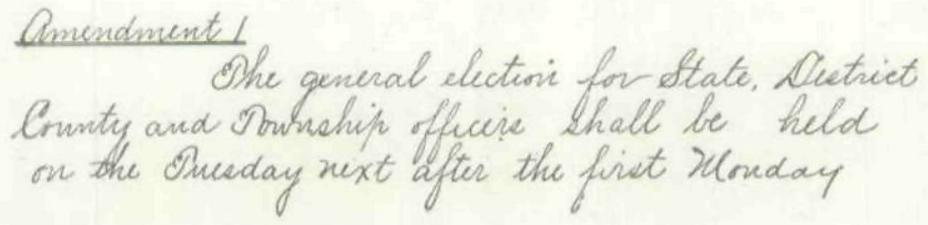


in Toventer.

\section{Amendenent 2}

Asembly. the ot any regular sescon of the beneral

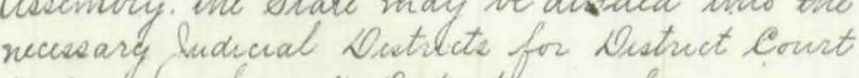
hurnoses, on the said Dustruct may be reorganged 'and the number of the Dritrecte and the blagee said Courte increased os dimunched; but no re-hque. igation of the Dietructe or duminution of the bedge shall have the effect is u...orng a yedge fiom iffici.

Quverdanent

QYu Siand kivy may consist of any number of surviere not tee than fire. nor hose thas intex as the Suresal Asembly may by law yilonde, or tiu linesal Osemble maly plovide for itideng iesurve to answer for dny chimenal offenes without the intervintion of a linand gury.

\section{Ameridment 4.}

$$
\text { That dection } 13 \text { of Article } 5 \text { of the }
$$
Constitution be etrecken therefrom and the following adrpted as euch dection.

dection 13. The givalified electore of each county shall. at the general election in the year 1856 and every two yeare thereafter elect a County Ottoney, who shall be a reedent of the connty for whlch he w elected, and shall hold hee Sfeer for two years, and until he succeser shall have been ilected and qualified

These amendments were proposed by the Nineteenth General Assembly, 1882, agreed to by the Twentieth General Assembly, 1884, ratified at the general election of November 4, 1884, and certified adopted on December 10, 1884. 
Facsimiles of the eleventh and twelfth amendments as engrossed and enrolled with the manuscript acts and joint resolutions of the Thirtieth General Assembly, 1904:

Nid es Section 16, to Article 12 of the constitution, the folloring:

Sec. 16. The first peneral election after the adoption of this amendment ahall be held on the Tuesiey next efter the first Nonday in November in the yeer ono thoussnd nine hundred end six, and general elections shall be held biennially thereafter In the year one thousend nine hunired and $s i x$ there shall be elected a governor, lieutenant-ijovernor, secretary of state, auditor of state, treasuror of stats attomey conersl, two juices of the suprems court, the successors of the judges of the district court whose terrss of office expire on December 31st, one thousend nine hindred end six, stato senetors who would othervise be chosen in the year one thou sond nizo hundred ext five, end nombers of the house of representativea. The terma of office of the judies of the suprene court which would othervise expire on Decernber 31st, in odd numbered yoers, and all other elective state, county and townahip officers those tenus of office trould othervise expire in Jenuary in the year one thousend nine hundred and six, end inembers of the general axsembly whose successors would otlervise be chosen at the ceneral election in the year one thousend nine bundred exd five, sre hereby extended orse year and until tioir successors are elected end cuellified. The terms of offices of senetors mhose sussensors rould otherrise be choson in the yeat one thousand nine hundred and seven are hereby extended one year end until thelr successors are elected end qualified. The generel assenbly stall make such chences in the law governing the tire of olection and term of office of e.l other elective officers as shell be necessery to meke the time of their eleotion and terms of office conform to this amendrent, and shall provide which of the judges of the supreme court shell serve as chief justice. The Eonerel asasmbly shall meet in reculer session on the second lionday in Jenuary, in the yeer one thousand nine hundred axd six, end also on the second isoriey in Jenuery in the year ons thousand ninę huadrod and seven, end bionnielly thereafter. 
That Sections thirty-four(34) thirty-five (35) and thirty-six(36) of Articlo throe (3) of the constitution of the State of Iowa, be repealed and the following bo adopted in lieu thereof.

Section 34. The Senate shall be composed of iffty members to be elented from the several senatorial distriots, estahlinied hy law and at the next seraion of the general asseably held following the taking of the state and national consus, they shall be apportioned amon; the several counties or districts of tine state, according to population as shown by the last precetinz census.

Section 35. The House of Kepresentatives shall consiat of not more than one hundred and eisht menibers. The Ratio of representation shall be determined by dividing the whole number of the population of the state as shown hy the last preceling state or national census, by the nhole number of ccunties then existing or organized, but each county shall constitute one representative district and be entitiod to one representative, but each county havin, a population in excess of the ratio number, ss herein provided of three fiftins or more of such ratio number shall be entitled to one additional representative, but said addition shall extend only to the nine counties having the greatest population.

Section 36. The General Assevibly shall, at the first resular session held rollowing the adoption of this amendment, and at earh succecting rezular session held next aftor the taking of such census, fix the ratio of representation, and apportion the additional representatives, as herein hefore recuirel.

These amendments were proposed by the Twenty-ninth General Assembly, 1902, agreed to by the Thirtieth General Assembly, 1904, ratified at the general election of November 8, 1904, and certified adopted on November 29, 1904. 
Facsimile of the thirteenth amendment as engrossed and enrelled with the manuscript acts and joint resolutions of the Thirty-second General Assembly, 1907:

That there be added to action eichteen (IE) of article one (1) of the constitution of the State of Iowa, the following:

The generel assembly, however, may pass laws permitting the ownors of lands to construct drains, ditches, and levees for agricultural, sanitary or mining purposes across the lands of others, and provide for the organization of drainage districts, vest the proper autborities with power to construct and maintain levees, drains and di tches and to keep in repair all dreins, di tches, and levees horetofore constructed under the laws of the state, by special assessments upon the rroperty benefited thereby. The general assembly may provide by law for the condemnation of such real estate as shall be necessary for the construction and maintenance of such drains, ditches and levees, and prescribe the method of making euch condemnation.

This amendment was proposed by the Thirty-first General Assembly, 1906, agreed to by the Thirty-second General Assembly, 1907 , ratified at the general election of November 3, 1908, and certified adopted on November 23, 1908.

Facsimile of the fourteenth amendment as engrossed and enrolled with the manuscript acts and joint resolutions of the Thirty-sixth General Assembly, 1915:

To repeal section seven (7) of article two (2) of the constitution of lows and to adopt in lieu thereof the follorine. to-rit:

"The general election for state, district, county and tomship officers in the year 1916 shall be held in the aeme month and on the same day es thet fixed by the Iews of the United States for the election of presidentisl electors, or of president and vice-president of the United States; and therester such election ahall be bold at such time as the general assembly may by law ptovida."

This amendment was proposed by the Thirty-fifth General Assembly, 1913, agreed to by the Thirty-sixth General Assembly, 1915, ratified at the general election of November 7, 1916, and certified adopted on November 27, 1916. 


\section{Proposed Amendments That Falled at the Electorate or in THE COURTS \\ II}

It will be noticed that in Section 14 of Article XII of the Constitution it was provided that a proposition should be submitted to amend that instrument, at the same time it was submitted to the people for adoption, by striking out the word "white" from Article II, the one on the right of suffrage. This was done by furnishing a separate ballot to each voter. If the number of ballots cast in favor of the proposition should be equal to a majority of those cast for and against the Constitution then the word "white" would be declared stricken from said article. The election was held on August 3, 1857, and the number of votes cast for the Constitution was 40,311, while the number against it was 38,681 . A majority of those "for and against" was 39,497 . The number of votes cast for the proposed amendment was 8,489 , while the number against it was $49,387,{ }^{2}$ therefore the proposed amendment was lost. ${ }^{3}$

In 1880 the General Assembly proposed and in 1882 agreed to an amendment as follows:

Add as Section 26 to Article I of said Constitution the following: Section 26. No person shall manufacture for sale, or sell or keep for sale, as a beverage any intoxicating liquors whatever, including ale, wine and beer.

The General Assembly shall by law preseribe regulations for the enforcement of the prohibition herein contained, and shall thereby provide suitable penalties for the violation of the provisions hereof. . $^{-}$

This amendment was ratified at a special election held June 27,1882 , by a vote of 155,436 for, to 125,677 against, ${ }^{5}$ a majority of 29,759, and was proclaimed adopted on July 28, 1882.

2Archives Division of the Historical Department of Iows.

sIt is interesting to know that with a population of 517,875 in 1856 the state in 1857 cast 78,922 votes for and against the Constitution, or 1 vote for each 6.56 persons in the state. On the proposed amendment it cast only 1 vote for each 8.95 persons. But this showed more interest in that proposed amendment than is sometimes manifested in amendments. For example, on the amendment submitted in 1884 to change the date of general election for state, district. county, and township officers, only 1 vote was cast for each 16.82 persons then in the state. However, in 1882 there was cast on the prohibition amendment 1 vote for each 5.77 persons, and in 1896 at the general election there was cast 1 vote for each 3.95 persons, which surely was almost a full vote.

4Enrolled acts and joint resolutions of the Nineteenth General Assembly, in the Office of the Secretary of State.

DArchives Division of the Historical Department of Iowa. 
On April 21, 1883, the Supreme Court in Koehler \& Lange vs. Hill, 60 Iowa, 543, held that the amendment was not legally submitted to the electors, and hence did not become a part of the Constitution. The history of the amendment shows that it was first proposed in the House of the Eighteenth General Assembly, adopted, and sent to the Senate. That body adopted a substitute and sent it to the House. The House agreed to the substitute, but in the enrolled proposed amendment, signed by the presiding officers of both the House and Senate, the language did not agree with the language of the substitute adopted by the Senate, as shown by the Senate's journal, the words "or to be used" being omitted in the enrolled proposed amendment. The proposed amendment in the enrolled form was agreed to by the Nineteenth General Assembly, and was adopted by the people at the special election, but the court held that as its language materially differed from that of the one proposed by the Senate of the Eighteenth General Assembly that the provisions for amending the Constitution had not been complied with. Notwithstanding this, and the defeat at the polls of a like proposed amendment in 1917, the result aimed at was reached through statutory enactment, reinforced by the Eighteenth Amendment to the Federal Constitution, adopted in 1919.

In 1913 the General Assembly proposed and in 1915 agreed to a woman suffrage amendment as follows:

Section 1. That the following amendment to the Constitution of the state of Iowa is hereby proposed, towit:

Repeal Section 1 of Article II of the Constitution of the state of Iowa and in lieu thereof enact and adopt the following towit:

Section 1. Every citizen of the United States, of the age of twentyone years, who shall have been a resident of this state six months next preceding the election, and of the county in which he or she claims his or her vote, sixty days, shall be entitled to vote at all elections which are now or hereafter may be authorized by law. ${ }^{6}$

This amendment was submitted to vote at the primary election on June 5, 1916, the result being 162,683 for, to 173,024 against, $^{7}$ which defeated it by 10,341 votes.

It was proposed again in practically the same form by the

6Enrolled acts and joint resolutions of the Thirty-sixth General Assembly, in the Office of the Secretary of State.

Archives Division of the Historical Department of Iowa, 
General Assembly in 1917. The Constitution provides that an amendment proposed by one general assembly shall be referred by it to the legislature to be chosen at the next general election: "and shall be published as provided by law, for three months previous to the time of making such choice," and Section 55 of Chapter V of the Code provides that "the secretary of state shall cause the same to be published, once each week, in two newspapers of general circulation in each congressional district in the state, for the time required by the Constitution." This required publication was neglected, which resulted in the proposed amendment's second failure. It was proposed once more, this time by the General Assembly in 1919. On July 2, 1919, the General Assembly was called in special session and on that date ratified an amendment to the Federal Constitution providing for woman suffrage. That amendment was ratified by a sufficient number of states so that it became a part of the Federal Constitution, which made further action on the subject by the General Assembly unnecessary.

In 1915 the General Assembly proposed and in 1917 agreed to the following amendment:

Section 27. The manufacture, sale, or keeping for sale, as a beverage, of intoxicating liquors, including ale, wine and beer, shall be forever prohibited within this state. The General Assembly shall by law prescribe regulations for the enforcement of the prohibition herein contained, and shall provide suitable penalties for the violation of the provisions hereof. ${ }^{8}$

This amendment was submitted to a vote of the people at a special election on October 15, 1917. There were 214,693 votes cast for the amendment and 215,625 against it, so it was defeated by 932 votes. ${ }^{9}$

In 1923 the Fortieth General Assembly proposed an amendment to remove the obstruction to women being elected to membership in our legislative department, and it now awaits action by the Forty-first General Assembly. It is in the following language:

Section 1. That the following amendment to the Constitution of the state, be and the same is hereby proposed, viz:

8Enrolled acts and joint resolutions of the Thirty-seventh General Assembly, in the Office of the Secretary of State.

Election Returns of 1917 , in the Office of the Secretary of State. 
Strike out the word "male" from Section 4 of Article III of said Constitution, relating to the legislative department. ${ }^{10}$

\section{A Convention to Amend}

\section{III}

Section 3 of Article $\mathrm{X}$ of the Constitution provides "at the general election to be held in 1870 and in each tenth year thereafter, and also at such times as the General Assembly may by law provide, the question, 'Shall there be a convention to revise the Constitution and amend the same?' shall be decided by the electors qualified to vote for members of the General Assembly." This question was submitted in 1870, and regularly each tenth year thereafter, and always the majority was in the negative until 1920 when the result was: for the convention, 279,652; against the convention, 221,763; majority for the convention, 57,889. Section 3 of Article X reads further, "and in ease a majority of the electors so qualified, voting at such election, for and against such proposition, shall decide in favor of a convention for such purpose, the General Assembly, at its next session, shall provide by law for the election of delegates to such convention." The Thirty-ninth General Assembly, which met January 10, 1921, was the "next session" and four bills were introduced on the subject, two in the Senate and two in the House. The first was on January 20, House file 307, by Calhoun of Van Buren and Rankin of Lee, "a bill for an act making provision for a convention to revise and amend the Constitution, naming the number of delegates and districts, fixing the time for the convening of the Convention and provision for submitting the amendments and additions to a referendum."

February 12, Carter of Hardin introduced one of similar purport, House file 501, but on March 15 withdrew it. On January 25, Senator Wichman of Hancock introduced Senate file 343. It was reported out favorably on March 15 from the Committee on Constitutional Amendments of which Senator Wichman was chairman. A few days later it was taken up, amended, and the following day withdrawn by the author, evidently in the interest

\footnotetext{
10Enrolled acts and joint resolutions of the Fortieth Genernl Assembly, in the Office of the Secretary of State.
} 
of House file 307. On February 12 Senator Cessna of Poweshiek introduced Senate file 492, but on March 20 withdrew it.

House file 307 was reported out February 22 by the House Committee on Constitutional Amendments, of which Edson of Buena Vista was chairman. The report recommended all be stricken out after the enacting clause and a substitute adopted, which was done. Later amendments were filed and on March 15 the bill was taken up, the amendments adopted and the bill passed. April 1 it was received back from the Senate, having been amended and passed. April 6 the House refused to concur in the Senate amendments and appointed a Conference Committee. On April 8 the House adopted the report of the Conference Committee, but the same day reconsidered its action, defeated the report of the committee, appointed a second Conference Committee, then asked the Senate to return the bill to the House, which the Senate did, and the final adjournment of the session occurred the same day, leaving no enactment for the decennial election upon a constitutional convention.

\section{RETURNED TO HIS FIRST LOVE}

We see by the North-West that Charley Aldrich, one of the staunch pioneers in newspaper enterprises in the northwestern part of the state, has bought out Mr. Henderson of the Marshalltown Times and will enter upon his editorial duties on the 20th inst. Like a good many other men, Charley got a little tired of the drudgery of his profession and turned farmer. But how can a regularly born-and-bred quill driver like him be content while disconnected from the editorial sanctum? The idea of his finding permanent delight in raising grapes and melons is absurd. $\mathrm{He}$ is a born newspaper man and has no moral right to desert that profession which nature and education designed and fitted him to follow. Come back to your first love, friend, and don't desert it again. We assure the people of Marshalltown that they will find Mr. Aldrich a ready writer, a genial companion, a hardworking, radical politician, and an experienced editor, every way qualified to make for them a first-class paper.-Iowa State Register, September 6, 1866. (In newspaper collection of the Historical Department of Iowa.) 
Copyright of Annals of Iowa is the property of State of Iowa, by \& through the State Historical Society of Iowa and its content may not be copied or emailed to multiple sites or posted to a listserv without the copyright holder's express written permission. However, users may print, download, or email articles for individual use. 